\title{
A combined application of different engineering and biological techniques to remediate a heavily polluted river
}

\author{
Yanqing Sheng ${ }^{\mathrm{a}, *}$, Yingxuan $\mathrm{Qu}^{\mathrm{a}}$, Chaofeng Ding ${ }^{\mathrm{a}}$, Qiyao Sun ${ }^{\mathrm{a}}$, Robert J.G. Mortimer ${ }^{\mathrm{b}}$ \\ a Coastal Environment Engineering Technology Research Center of Shandong Province, Yantai Institute of Coastal Zone Research, Chinese Academy of \\ Sciences, Yantai 264003, China \\ b School of Earth and Environment, University of Leeds, Leeds LS2 9JT, UK
}

\section{A R T I C L E I N F O}

\section{Article history:}

Received 28 November 2012

Received in revised form 22 February 2013

Accepted 6 April 2013

Available online 4 May 2013

\section{Keywords:}

Polluted river

Aeration

Biological aerated filter

Bioremediation

China

\begin{abstract}
A B S T R A C T
River pollution is becoming a serious problem worldwide. A field-scale experiment was undertaken to remediate a heavily polluted river using a combined engineering approach of aeration, microorganisms, biological aerated filtration, artificial biofilms and ecological floating beds. Prior to remediation, the river water was black, anoxic and highly sulfidic. With remediation, the chemical oxygen demand decreased from $\sim 250$ to $\sim 50 \mathrm{mg} \mathrm{L}^{-1}, \mathrm{NH}_{4}{ }^{+}$-N decreased from $\sim 27$ to $\sim 4 \mathrm{mg} \mathrm{L}^{-1}$, sulfide decreased from $\sim 3$ to $\sim 0.3 \mathrm{mg} \mathrm{L}^{-1}$, and total suspended solids decreased from $\sim 270$ to $\sim 40 \mathrm{mg} \mathrm{L}^{-1}$. At the same time, dissolved oxygen increased from $\sim 0.1$ to $\sim 3.5 \mathrm{mg} \mathrm{L}^{-1}$, and water clarity increased from $\sim 6$ to $\sim 40 \mathrm{~cm}$. Furthermore, the unpleasant odor emanating from the polluted river was also stopped, and local farmers have begun using the water for irrigation. This field-scale experiment thus indicates the potential usefulness of this combined engineering approach to remediate heavily polluted rivers.
\end{abstract}

(c) 2013 Elsevier B.V. All rights reserved.

\section{Introduction}

Rapid industrialization, urbanization, and population growth has led to the pollution of rivers and degradation of ecosystems, especially in municipal rivers in developing countries (Scholes et al., 2008; Longe and Omole, 2008). River water is easily polluted by domestic wastewater effluent, rainwater, agricultural run-off, and industrial wastewater, which result in severe degradation of water quality, the water becoming black and odorous, and loss of fish (Scholes et al., 2008; Palmer, 2009; Caraballo et al., 2011). In northern China, the majority of rivers have been used for agricultural irrigation due to the shortage of water, especially in arid seasons. However, most of these rivers have become heavily polluted. Sewage is one of the main components of municipal river water in northern China, and Zhang et al. (2008) demonstrated that long-term sewage irrigation influences soil microorganisms and soil quality. Accordingly, remediation of river water quality has become a significant concern, both regionally and worldwide (Alvarez-Vázquez et al., 2009; Sheng et al., 2012). In situ bioremediation is a potentially effective process for purification of polluted surface water (Everard and Moggridge, 2012; Zhao et al., 2012). Indeed, many in situ remediation processes such as ecological floating bed techniques and constructed wetlands have been developed

\footnotetext{
* Corresponding author. Tel.: +86 535 2109152; fax: +86 5352109000.

E-mail address: yqsheng@yic.ac.cn (Y. Sheng).
}

for bioremediation of polluted surface waters (Sun et al., 2009; Vymazal, 2009; Wu et al., 2011). However, these techniques have many disadvantages, such as being time-consuming, costly and requiring significant space (Zhu et al., 2011; Meyer, 2012; Saeed and Sun, 2012). Techniques using combined biotechnological and engineering methods to remediate heavily polluted rivers have been attracting increasing attention in the environmental protection field (Arini et al., 2012; Sheng et al., 2012). This approach requires less time, space and cost compared to other technologies. There have been only a few reports concerning the remediation of heavily polluted rivers (e.g. Sun et al., 2009; El-Sheikh et al., 2010; Wu et al., 2011), and most of these studies were focused on off-line treatment or laboratory work (e.g. Palmer, 2009; Cao et al., 2012). This study focused on the application and efficiency of a comprehensive engineered bioremediation process for a heavily polluted river using a combination of aeration, microorganisms, optimized biological aerated filters (BAF), biofilms and ecological floating beds. The targets of this engineering are (1) decreasing the COD under $60 \mathrm{mg} \mathrm{g}^{-1}$; (2) decreasing the $\mathrm{NH}_{4}{ }^{+}-\mathrm{N}$ under $6 \mathrm{mg} \mathrm{g}^{-1}$; (3) ensuring the water quality is suitable for fish. Because there were no fish in tested river, they were added post treatment. The two objectives of our study were: (1) to assess the feasibility of applying different in situ treatment units to remediate a heavily polluted river; (2) to evaluate the water quality improvements and removal efficiency of chemical oxygen demand $\left(\mathrm{COD}_{\mathrm{Cr}}\right)$, ammoniacal nitrogen $\left(\mathrm{NH}_{4}{ }^{+}-\mathrm{N}\right)$ and other pollutants under continuous flow conditions. 


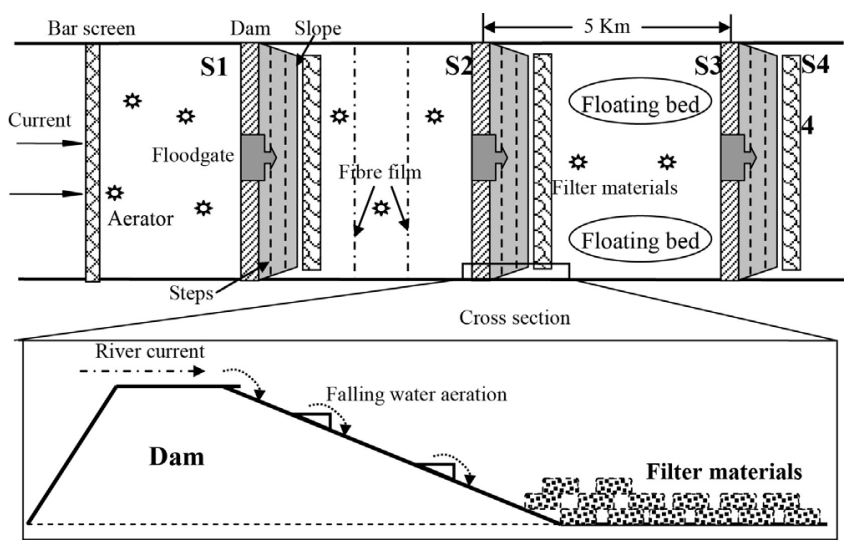

Fig. 1. Schematic diagram of field-scale field-scale set-up.

\section{Materials and methods}

\subsection{Description of treated river}

The Dihe River is located in the Changyi, Shandong Province, northern China $\left(36^{\circ} 25^{\prime} 36^{\prime \prime} \mathrm{N}, 119^{\circ} 13^{\prime} 42^{\prime \prime} \mathrm{E}\right)$. The climate is cold and dry in spring and winter, and warm and wet in summer and autumn, and is characterized by annual precipitation of $\sim 630 \mathrm{~mm}$ and an average temperature of $11.9^{\circ} \mathrm{C}$. The experimental reach is $23 \mathrm{~km}$ long, and averaged $30 \mathrm{~m}$ in width and $0.6 \mathrm{~m}$ depth. This river is a drainage river, originating from the Changyi City urban area, carrying about $80 \%$ of the municipal sewage of the city, which amounts to 90,000 tons per day. At the start of the study, the river water resembled black ink and gave off an unpleasant odor due to $\mathrm{H}_{2} \mathrm{~S}$ (this watercourse is locally referred to as the "black-odor river") (Wu et al., 2012). The thickness of sedimentary sludge on the river bed exceeded $1 \mathrm{~m}$, and this contained many toxic compounds, including Dechlorane Plus and organochlorine pesticides (Zhao et al., 2011; Zhong et al., 2011). Because of the serious pollution problem, local farmers had given up using this river water for irrigation many years ago. Although the local government has dredged and flushed the channel many times to try to resolve this problem, this has had little impact. Therefore, the water quality of this river has been steadily deteriorating, ultimately threatening the coastal water quality of Laizhou Bay, Bohai Sea, an important fishery.

\subsection{Design of field-scale experiment}

One bar screen and three dams were constructed from upstream to downstream (5 km interval) to maintain sufficient hydraulic retention time ( $\sim 24 \mathrm{~h})$ to ensure the growth and reproduction of the microbial system in the filters and on the biofilm substrate in the river. Each dam has a floodgate ( $2 \mathrm{~m}$ width) to drain floodwater in the rainy season. The height of these dams is $0.8 \mathrm{~m}$, with two $20 \mathrm{~cm}$ high steps ( $\sim 40 \mathrm{~cm}$ interval) on the downstream slope (obliquity is $\sim 30^{\circ}$ ) to aid oxygenation. Nine floating waterwheels (power consumption $1.5 \mathrm{~kW}$; Zibo Tianmiao Marine-Biological Technology Co., Ltd., Zibo, China) were placed within the experimental reach for use as aerators. The schematic diagram of the field-scale engineering set-up is shown in Fig. 1. The detailed elements of the engineering process were: (1) setting a steel bar screen in area S1 to prevent floating rubbish (Fig. 1); (2) constructing dams in areas S2, S3 and S4 to maintain enough hydrological retention time; (3) installing aerators in area S1, S2 and S3 at the beginning of the field experiment; (4) installing ecological floating beds with some local hydrophytic plants (such as cannas and candocks) in area S3; (5) dosing with microbiological reagents in areas S1, S2, S3 and S4 (Fig. 1).

High DO can enhance the removal of nutrients in water bodies (Albuquerque et al., 2012). In order to increase the DO in river water, aerators were installed in reach sections S1, S2 and S3 (Fig. 1) for emergency oxygenation at the beginning of the project or after heavy rain (when wastewater and sewage will be discharged directly into the river). Furthermore, the downstream slope of each dam was designed with two steps to further aerate the falling water.

Biofilm techniques are helpful in remediating polluted surface water (Fechner et al., 2012). The carrier for biofilms directly influences treatment efficiency and energy consumption (Cao et al., 2012). Inert carriers have a relatively long film-forming culture time and lower biomass for bioremediation of polluted surface water. Therefore, it is essential to seek a better carrier for more rapid biomediation of polluted surface water. In this study, Beier Film (patent protected, with $200-300 \mathrm{~m}^{2} \mathrm{~m}^{-3}$ specific surface area for microorganisms, Zhongyu Ecological Science and Technology Co. Ltd., Zhongshan, China) was used for artificial biofilms. This was suspended in the river water (S2 and S3, Fig. 1) by ropes with floats in order to increase biomass and prevent added organisms (microbial reagents) from flowing away with the river current.

In order to enhance the purification by ecological floating beds (Hadad and Maine, 2007; Shan et al., 2011; Jia et al., 2011), local hydrophytic plants were used to set up ecological floating beds along the riverbank at different locations. In order to recover the river ecosystem and also improve its esthetic appeal, mechanical aeration, biological aerated filters, artificial biofilms and ecological floating bed were all combined.

\subsection{Microbial reagents application}

Addition of photosynthetic bacteria (PSB) reagents and Bacillus subtilis powder can enhance the activity of organisms and aid improvements in water quality (Sheng et al., 2012; Khan et al., 2012). PSB and B. subtilis are found in many natural aquatic environments, where they remove pollutants (i.e. sulfide, $\mathrm{NH}_{4}^{+}-\mathrm{N}$ ) and enhance biological activity and water quality (Chen et al., 2000; Sheng et al., 2012; Nimrat et al., 2012). PSB are microorganisms that use sunlight as their energy source and use naturally occurring organic compounds and sulfur compounds as electron donors for photosynthesis (Chen et al., 2000). In this work, PSB were collected from the sedimentary sludge of the Dihe River itself after a series of enrichment, culture, separation and purification steps. Another microbial reagent (B. subtilis) applied in this experiment was also isolated from the Dihe River, carried on complex clay. PSB and B. subtilis were used to enhance the purification of the polluted river water and remove $\mathrm{C}, \mathrm{N}$, and remediate the heavily polluted sedimentary sludge (Sheng et al., 2012; Lu et al., 2012). PSB microbial reagent (total viable count $\sim 4 \times 10^{9} \mathrm{cfu} \mathrm{g}^{-1}$ ) and $B$. subtilis reagent (total viable count $\sim 5 \times 10^{8} \mathrm{cfu} \mathrm{g}^{-1}$ ) were from Yantai Institute of Coastal Zone Research, Chinese Academy of Sciences. A dosage rate of $10 \mathrm{mg} \mathrm{L}^{-1}$ was selected as the most appropriate concentration for PSB and B. subtilis to remedy the polluted water body (Sheng et al., 2012). In the field, the levels of biological reagent were calculated based on the water volume capacity between two dams and runoff. The microbial reagents were directly diluted with river water and distributed evenly over the river surface. Dosing frequency was weekly at the beginning of the experiment, but was then decreased each month as the engineering progressed, based on the measured quality of the recovering river-water. 
Table 1

The average parameters of polluted river water and sediment (unit: $\mathrm{mg} \mathrm{L}^{-1}$ ).

\begin{tabular}{|c|c|c|c|c|c|c|c|c|}
\hline Water sample & $\mathrm{COD}_{\mathrm{Cr}}$ & TSS & $\mathrm{NH}_{4}^{+}-\mathrm{N}$ & $\mathrm{TP}$ & $\mathrm{S}^{2-}$ & DO & $\mathrm{pH}$ & Water clarity $(\mathrm{cm})$ \\
\hline Upstream & 257 & 273 & 27.4 & 1.6 & 3.4 & 0.1 & 8.2 & 4 \\
\hline Downstream & 209 & 184 & 22.6 & 1.1 & 2.9 & 0.8 & 7.8 & 6 \\
\hline Standard (V) & 40 & - & 2 & 0.4 & 1.0 & 2 & $6-9$ & - \\
\hline US Standard & - & 40 & 0.5 & 0.1 & 2 & 3 & $6.5-8.5$ & - \\
\hline Sediment & \multicolumn{2}{|c|}{ TOC (\%) } & $\mathrm{TN}(\%)$ & \multicolumn{2}{|r|}{ TS (\%) } & \multicolumn{2}{|c|}{ Total Fe $\left(\mathrm{mg} \mathrm{g}^{-1}\right)$} & Sulfide $\left(\mathrm{mg} \mathrm{g}^{-1}\right)$ \\
\hline Upstream & \multicolumn{2}{|c|}{8.9} & 1.6 & \multicolumn{2}{|r|}{0.9} & \multicolumn{2}{|c|}{15.2} & 6.3 \\
\hline Downstream & \multicolumn{2}{|c|}{6.7} & 1.1 & \multicolumn{2}{|r|}{0.7} & \multicolumn{2}{|c|}{14.8} & 4.5 \\
\hline
\end{tabular}

\subsection{Filter materials, biofilms, ecological floating bed and fish fry preparation}

Media used in biological aerated filters (BAF) must have suitable specific surface area to allow good biofilm development (Albuquerque et al., 2012). A mixture of converter slag and coal cinder can be used as adsorbent for the removal of phosphorous, COD and $\mathrm{NH}_{4}{ }^{+}-\mathrm{N}$ (Yang et al., 2009). Coal cinders produced by a local electricity factory were selected as filter materials for this field experiment. The diameter of these irregular cinders was $\geq 10 \mathrm{~cm}$. They were packed in nylon net bags (mesh diameter $\sim 6 \mathrm{~cm}$ ), each containing $\sim 30 \mathrm{~kg}$ of cinders. During the field experiment, these cinder bags were overturned periodically to rinse and unclog them and allow better flow-through to be reestablished. Beier film was suspended in the river water to increase biomass and prevent added organisms from flowing away with the river current.

Macrophyte restoration using floating, emergent and submersed plants is considered crucial to regulating lake biological structure, limiting algal growth by competing for nutrients and sunlight, and also increasing herbivorous fish biomass by providing food and refuge (Thiébaut et al., 2006; Brisson and Chazarenc, 2009; Li et al., 2010). Planted floating-beds can be used for treating eutrophic water in a simple and cost-effective manner (Nahlik and Mitsch, 2006; Hadad and Maine, 2007; Li et al., 2010). Plants using for ecological floating beds in this work were local hydrophytic plants, such as aquatica, candocks, and water spinach (Ipomoea aquatica Forsk.). Some of them are vegetables in China and are also widely used for water pollution control (Li et al., 2007; Song et al., 2009). Water spinach has a world-wide distribution in tropical and subtropical warm regions and is a fast-growing herbaceous vine commonly found along muddy stream banks or floating in freshwater marshes and ponds. The framework of floating bed was made using $10 \mathrm{~cm}$ diameter bamboo and was $2.5 \mathrm{~m}$ long and $1.5 \mathrm{~m}$ wide. Fish fry $(\sim 8 \mathrm{~cm}$ Ctenopharyngodon idellus, a cyprinoid) were purchased from local fishery. Fry were added to the river during the engineering process, when the COD and $\mathrm{NH}_{4}{ }^{+}-\mathrm{N}$ decrease to 80 and $8 \mathrm{mg} \mathrm{g}^{-1}$, and the DO exceeded $2 \mathrm{mg} \mathrm{L}^{-1}$.

\subsection{Sampling and analysis}

All sampling equipment and storage containers were cleaned with distilled water before use, and all water samples were collected without disturbing the sediment-water interface. Water samples were collected in 500-ml polypropylene bottles from midstream at about $0.2 \mathrm{~m}$ below the water surface. The bottles were completely filled with water (no bubbles or headspace), sealed with gastight screw caps, and kept in an icebox under an inert $\left(\mathrm{N}_{2}\right)$ atmosphere. Water samples were collected at site $\mathrm{S} 4$ at regular intervals and were analyzed in triplicate within $24 \mathrm{~h}$. Chemical oxygen demand $\left(\mathrm{COD}_{\mathrm{Cr}}\right)$, total suspended solid (TSS), sulfide (total
$\mathrm{S}^{2-}$ ), $\mathrm{NH}_{4}{ }^{+}-\mathrm{N}$ and Total dissolved $\mathrm{P}(\mathrm{TP})$ were measured with the methods specified in the standard methods for the examination of water and wastewater (APHA, 1998). DO, pH and temperature (T) were measured using YSI 550A Handheld Dissolved Oxygen and Temperature System purchased from TechTrend International Limited, USA. A secchi disc was used to measure water clarity. Surface sediments were collected using a stainless steel spatula and were immediately placed in 250-ml polypropylene containers. The containers were fully filled with sediment and sealed with gas-tight screw-caps. Before analysis, all sediment samples were homogenized by mixing with a glass rod under a stream of $\mathrm{N}_{2}$. Total organic carbon (TOC) was determined by Shimadzu TOC-VCP (Japan), and total sulfur (TS) and total nitrogen (TN) were determined using an Elemental Analyzer (Elementar, Vario EL cube, Germany). The purity level of all chemical reagents used in the analysis was analytical reagent or better, and analytical precision was to within $<5 \%$. The glassware and plastic ware were soaked in $1 \mathrm{M} \mathrm{HCl}$ and rinsed with de-ionized water prior to use.

The initial fieldwork was conducted on May 15th, 2010. About one month later, a steel bar screen, three dams and boiler coal cinders bags were prepared. On July 10th, section S1, S2, S3 and S4 were filled with river water, then aquatic fiber films and ecological floating bed were conducted in corresponding sections (Fig. 1). Water samples were collected at S4 and analyzed every 15 days to determine the removal efficiency.

\section{Results and discussion}

\subsection{Characteristics of water quality and sediment of tested river}

The concentrations of different pollution parameters in the water samples and sediments are presented in Table 1 (sampling and analysis date was June 5th, 2010). For water samples, the average concentrations of $\mathrm{COD}_{\mathrm{Cr}}$, TSS, TP and $\mathrm{NH}_{4}{ }^{+}-\mathrm{N}$ were much higher than the lowest Chinese Standard level (V), US Standard and EU Standard level for surface water quality (Table 2). For $\mathrm{COD}_{\mathrm{Cr}}$, this river is similar to the Ciliwung River in Indonesia but higher than Koayase River in Japan (Kido et al., 2009). In terms of overall pollution level, this river is similar to the Borkena River in Belgium and rivers in some developing countries (Beyene et al., 2009). The average concentrations of TOC, TN and TS in surface sediments were $7.8 \mathrm{wt} \%, 1.4 \mathrm{wt} \%$ and $0.8 \mathrm{wt} \%$, respectively. The clarity of this polluted river water was only $\sim 5 \mathrm{~cm}$, and there was an obvious unpleasant odor of $\mathrm{H}_{2} \mathrm{~S}$ (Wu et al., 2012). We observed almost no algae or zooplankton living in the water body. Sediment sulfide and total Fe concentrations reached to $6.3 \mathrm{mg} \mathrm{g}^{-1}$ and $15.2 \mathrm{mg} \mathrm{g}^{-1}$, respectively, showing that conditions were highly anoxic. Therefore, the remediation strategy was based around oxidation of the iron and sulfide, together with providing an enhanced microbial and plant community to help tackle the elevated TOC and nutrients that were driving the anaerobic microbial activity. 
Table 2

The average parameters of river water after remediation (unit: $\mathrm{mg} \mathrm{L}^{-1}$ ).

\begin{tabular}{|c|c|c|c|c|c|c|c|c|}
\hline Water & $\mathrm{COD}_{\mathrm{Cr}}$ & TSS & $\mathrm{NH}_{4}^{+}-\mathrm{N}$ & $\mathrm{TP}$ & $\mathrm{S}^{2-}$ & DO & $\mathrm{pH}$ & Water clarity $(\mathrm{cm})$ \\
\hline Mean value ${ }^{a}$ & 53 & 27 & 4.5 & 0.2 & 0.3 & 3.9 & 7.6 & 37 \\
\hline Standard (V) & 40 & - & 2 & 0.4 & 1.0 & 2 & $6-9$ & - \\
\hline
\end{tabular}

a These values are means calculated from the data during 23rd August-15th December, 2010.

\subsection{Remediation efficiency for $\mathrm{COD}_{\mathrm{Cr}}, \mathrm{NH}_{4}{ }^{+}-\mathrm{N}$ and TSS in downstream}

The initial concentrations of each pollutant were measured on the first day of the fieldwork. All pollutant parameters were analyzed in the laboratory except for $\mathrm{pH}, T$ and $\mathrm{DO}$, which were measured in the field. Detailed results are shown in Fig. $2 . \mathrm{COD}_{\mathrm{Cr}}$ decreased from 232 to $37 \mathrm{mg} \mathrm{L}^{-1}$, then increased to $\sim 50 \mathrm{mg} \mathrm{L}^{-1}$, which is close to the level V Chinese Standard $\left(40 \mathrm{mg} \mathrm{L}^{-1}\right) . \mathrm{NH}_{4}{ }^{+}-$ $\mathrm{N}$ decreased from 22.6 to $3.3 \mathrm{mg} \mathrm{L}^{-1}$, then increased to $\sim 5 \mathrm{mg} \mathrm{L}^{-1}$, which was still higher than level V Standard $\left(2 \mathrm{mg} \mathrm{L}^{-1}\right)$. It can be seen from Fig. 2 that after 21st August, the reduction of $\mathrm{COD}_{\mathrm{Cr}}$, $\mathrm{NH}_{4}{ }^{+}-\mathrm{N}$ and TSS reached $\sim 85 \%$. This phenomenon can be explained by following processes: (1) the hydraulic retention time was prolonged by constructed dams, which enhanced the sedimentation of pollutants and suspended solids in the river water; (2) the artificial aeration increased the DO level in the water body, which provided stronger oxidation to degrade the pollutants (Albuquerque et al., 2012); (3) after one month, the microbial community in the water body, BAF and artificial biofilms will have built up, enhancing the removal of pollutants (Cao et al., 2012; Sheng et al., 2012); (4) the plant roots of the ecological floating bed began to consume the C, N, P as nutrition (Hadad and Maine, 2007; Jia et al., 2011). In this work, filter materials (coal cinders) used in BAF and artificial biofilms (Beier Film) have specific surface area for biofilm production, providing living space for PSB, $B$. subtilis and nativeborn microorganisms. These microorganisms can consume sulfur compounds, $\mathrm{NH}_{4}{ }^{+}-\mathrm{N}$ and organic compounds to decrease odor pollution. Besides direct consumption, plant roots spreading like fiber mats in water perform as filters and catch floating objects. In the plant root sphere, zooplankton and small creatures feeding on the substances filtered by plants' roots multiply, and food chains are formed (Song et al., 2009). Furthermore, the rhizosphere is of high importance for contaminants removal due to the release of oxygen from the plant roots into the surrounding environment, various microbiological transformations, such as mineralization of organic carbon, nitrification, denitrification and oxidation of $\mathrm{S}^{2-}$ compounds occur simultaneously on a small spatial scale (Wu et al., 2012). Finally, pollutants transformed into the organisms are taken out of the water, which decreased the $\mathrm{COD}_{\mathrm{Cr}}$ and $\mathrm{NH}_{4}{ }^{+}-\mathrm{N}$ indirectly.

TSS decreased from 173 to $21 \mathrm{mg} \mathrm{L}^{-1}$, and then increased to $\sim 26 \mathrm{mg} \mathrm{L}^{-1}$ (removal rate $88 \%$ ). TSS was mainly caused by the strong water current, which distributed the sedimentary sludge throughout the river water, leading to a higher measured pollutant level. In this experimental reach, the dams have slowed the current and hence reduced the resuspension of bed load. Furthermore, with the engineering process conducted, suspended solids with small particle size were filtered by the series of BAFs (Albuquerque et al., 2012). Although the aerators disturbed the sedimentary sludge, the solids re-deposited out of the influence scope of aerators. TP decreased from 1.4 to $0.1 \mathrm{mg} \mathrm{L}^{-1}$, and then increased to $\sim 0.3 \mathrm{mg} \mathrm{L}^{-1}$. The results indicated BAF process and ecological floating bed can remove phosphate (Yang et al., 2009; Shan et al., 2011), decreasing TP concentration significantly.
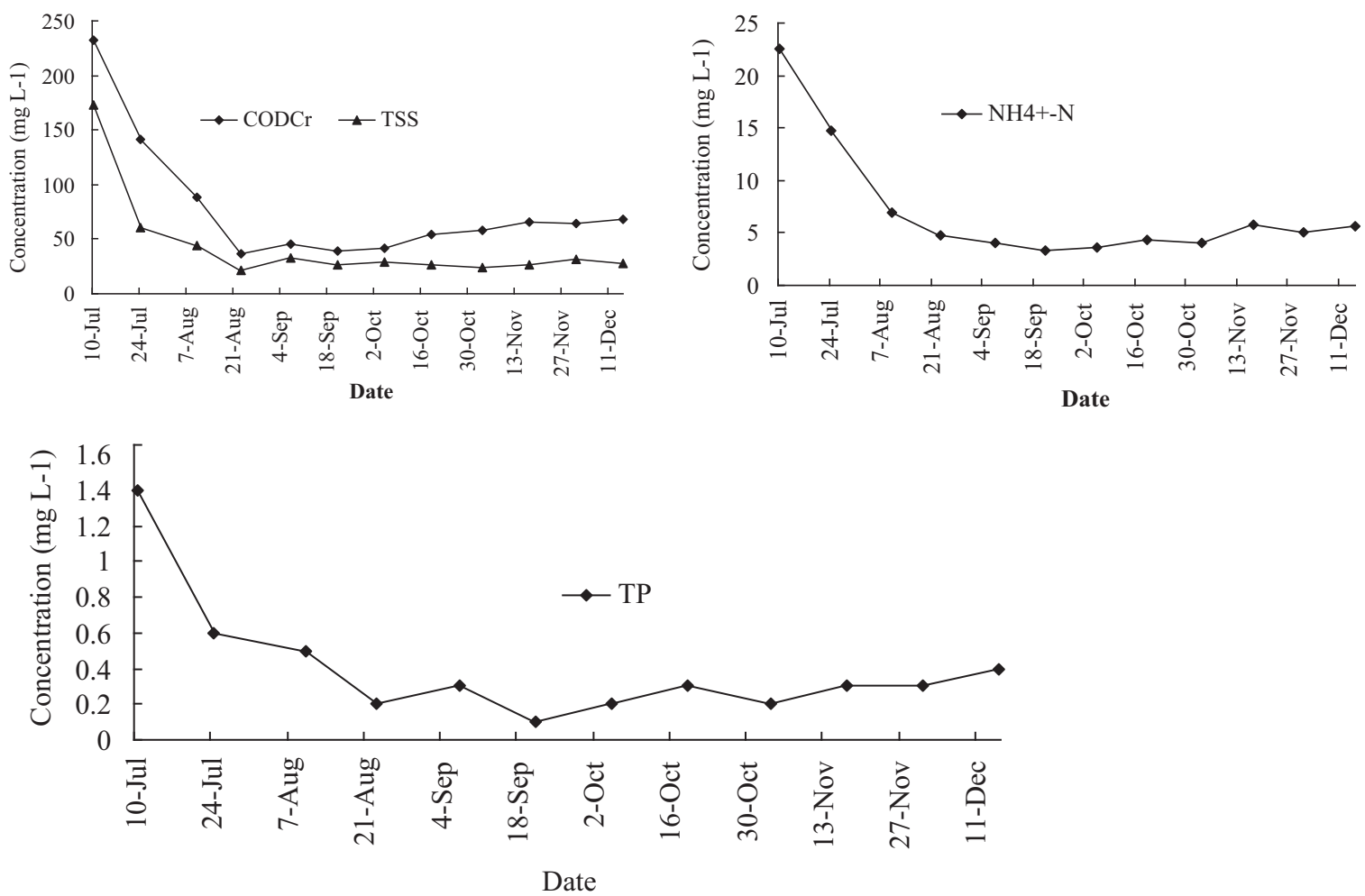

Fig. 2. The variations of $\mathrm{COD}_{\mathrm{Cr}}$, TSS and $\mathrm{NH}_{4}{ }^{+}-\mathrm{N}$ in river water. 

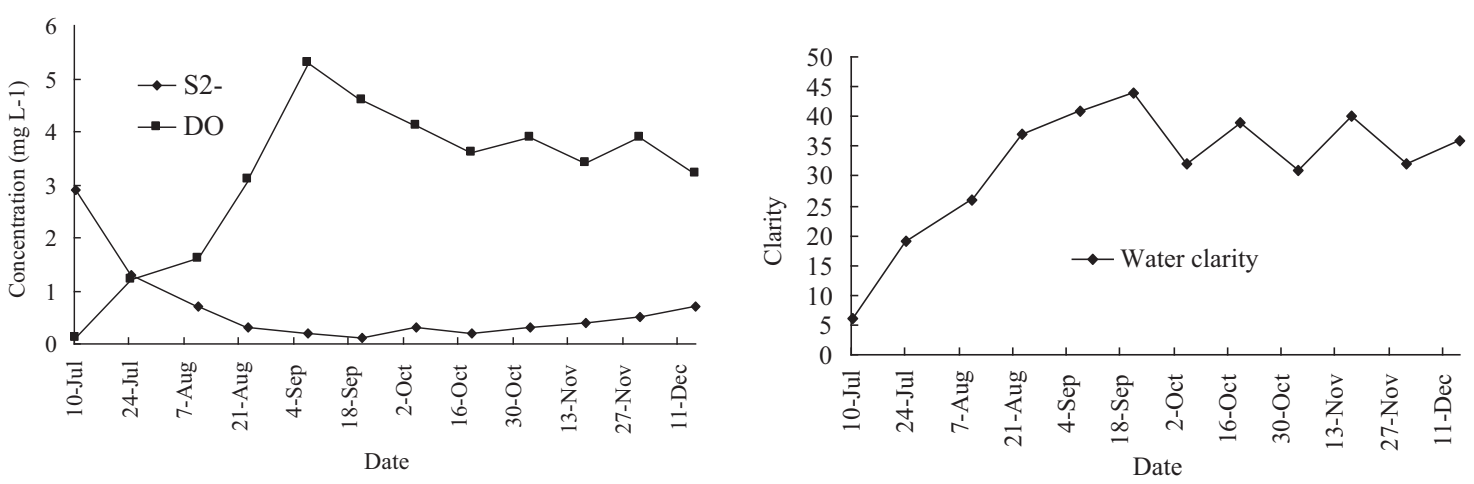

Fig. 3. The variations of $\mathrm{TP}, \mathrm{S}^{2-}$, DO and water clarity in river water.

\subsection{Variation of $D O, S^{2-}, T P$ and water clarity}

DO increased dramatically during the remediation process (Fig. 3). Two months after the beginning of the engineering, the DO concentrations exceeded $3.5 \mathrm{mg} \mathrm{L}^{-1}\left(>2 \mathrm{mg} \mathrm{L}^{-1}\right)$, at which point all running aerators were stopped intermittently to decrease the running costs. On October 2 nd, the concentrations of various pollutants increased abruptly due to the inrush of a large flood caused by heavy rainstorms. When such incidents occurred, a calculated quantity of supplementary reagents was dosed immediately, and the aerators were operated simultaneously.

As showed in Fig. 3, DO increased from 0.1 to $5.6 \mathrm{mg} \mathrm{L}^{-1}$, then decreased to $\sim 3 \mathrm{mg} \mathrm{L}^{-1}$. Water clarity increased from 6 to $44 \mathrm{~cm}$, and then fluctuated around $32 \mathrm{~cm}$. Total $\mathrm{S}^{2-}$ decreased from 2.9 to $0.1 \mathrm{mg} \mathrm{L}^{-1}$, then increased to $\sim 0.2 \mathrm{mg} \mathrm{L}^{-1}$. Aeration led to oxygenation and oxidation, during which $S^{2-}$ reached nearly zero. In heavily polluted river, the odorous compounds, especially the odorous volatile sulfur containing compounds will be produced and release from anaerobic water bodies (Sheng et al., 2008, 2011). In this work, the average final value of DO was $\sim 3 \mathrm{mg} \mathrm{L}^{-1}$, the production of reduced sulfide was restrained, so the odorous pollution was decreased. After two months of comprehensive remediation, chironomid larvae, algae and duckweed occurred in river water, the ecosystem in the water body gradually began to recover.

For the whole engineering process, there were very significant initial improvements in $\mathrm{COD}_{\mathrm{Cr}}, \mathrm{NH}_{4}{ }^{+}-\mathrm{N}, \mathrm{TSS}, \mathrm{TP}, \mathrm{S}^{2-}$, DO and water clarity up to 21 st August, but then a slight relaxation toward slightly worse values. This reflects effective engineered systems at the start of the project, followed by local rainy season is July and August, there are many during this period, increasing run off over polluted land, then water quality was influenced by the big flood frequently.

\subsection{Relationships of DO-water clarity, DO-S $\mathrm{S}^{2-}$ and $\mathrm{S}^{2-}$-water clarity}

The relationships of DO-water clarity, DO- $\mathrm{S}^{2-}$ and $\mathrm{S}^{2-}$-water clarity in river water are illustrated in Fig. $4 . R^{2}$ of DO-water clarity was 0.78 , a statistically significant positive correlation, clearly indicating that DO controls water clarity. However, $R^{2}$ of DO- $S^{2-}$ and $\mathrm{S}^{2-}$-water clarity were 0.73 and 0.85 , respectively, both statistically significant negative correlations. This suggests that increased water clarity is effectively limited by the $S^{2-}$ concentration, and $\mathrm{S}^{2-}$ is effectively limited by the DO. In this engineering experiment, artificial aeration and falling water aeration increased the DO and maintained a high level in the water body, which enhanced the growth and reproduction of natural and added microbes, strengthening the self-purification capability of the water. Generally, the production of sulfide is the main reason for the river water becomes black. In this work, prior to treatment, the river was full of suspended particles, including FeS. The particles and FeS prevented algae etc., further restricting DO. Aeration raised the DO and caused oxidation of the FeS and the engineering also changed the flow regime, allowing sedimentation to dominate over suspension. Oxidation of FeS and sedimentation improved clarity and the higher DO plus the seeding with microorganisms and plants allowed primary producers to re-colonize, restarting the usual diurnal cycle of photosynthesis and respiration. DO caused a reduction in sulfide, which caused an increase in clarity. High DO restrained the production of any further $\mathrm{H}_{2} \mathrm{~S}$ within the water column and at the same time $\mathrm{Fe}^{2+}$ in river water was oxygenated to $\mathrm{Fe}(\mathrm{OH})_{3}$ (river water $\mathrm{pH}$ $\sim 7$ ), which fell to the sediment surface (Perera et al., 2010). Freshly formed $\mathrm{Fe}(\mathrm{OH})_{3}$ has a high sorption capacity for pollutants such as phosphate (Slomp et al., 1996) and hence this provides the river with additional self-cleansing capacity.

\subsection{Present conditions of the tested river}

After two months of continuous comprehensive remediation, the quality of the water has shown an obvious improvement, with average removal rates of $\mathrm{COD}_{\mathrm{Cr}}$, TSS, $\mathrm{NH}_{4}{ }^{+}-\mathrm{N}, \mathrm{TP}$ and $\mathrm{S}^{2-}$ all above $70 \%$ (Table 2). The sporadic work of dosing reagents and cleaning the river water surface is all that is needed at present to maintain this new level of water quality, because a healthy ecosystem has built up in the river. Pollutant levels have remained stable at these
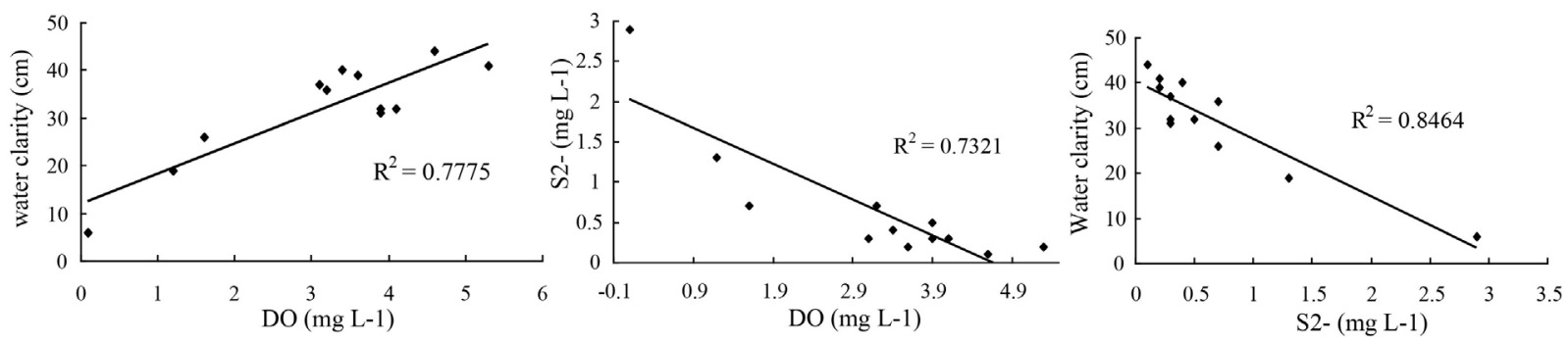

Fig. 4. Relationships between DO, $\mathrm{S}^{2-}$ and water clarity in river water. 

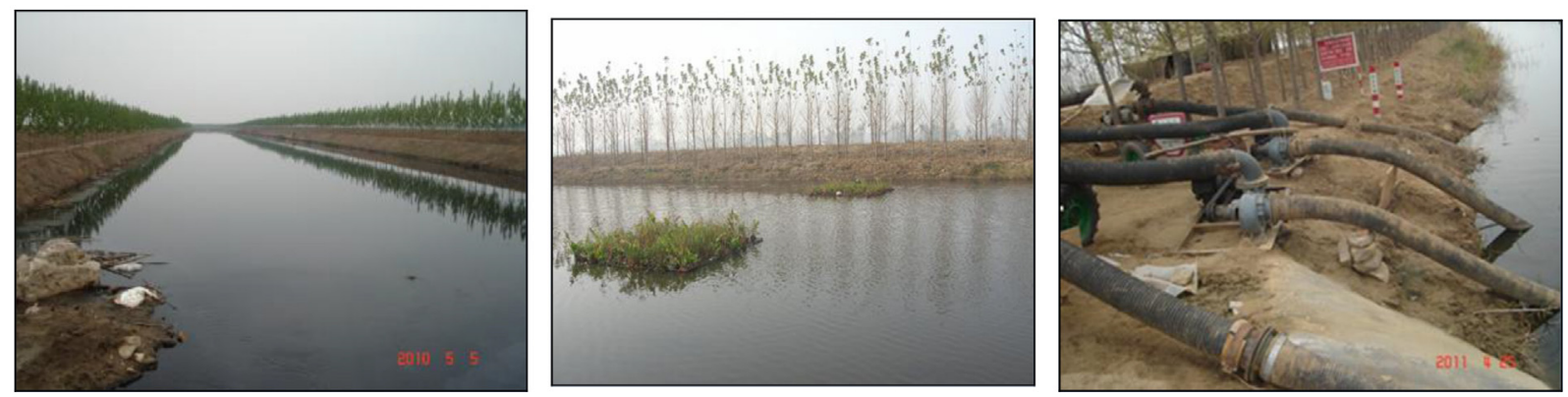

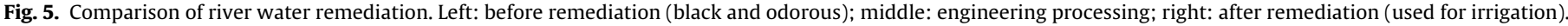

much lower concentrations, and consequently local farmers began to use the river water for irrigation again (Fig. 5). Visual and sporadic chemical monitoring along will be necessary over the coming years to ensure that the recovery is sustainable over the long term, particularly if abstraction levels increase significantly.

There are a great numbers of algae, zooplankton and a number of fish living in the river. There is no longer any smell of sulfide. The river now has a stronger capability to cleanse itself, some pollutants have reached or are approaching levels meeting Degree V of the State Standards for surface water, and the key project targets $\left(\mathrm{COD}_{\mathrm{Cr}}\right.$ and $\mathrm{NH}_{4}{ }^{+}-\mathrm{N}$ below 60 and $6 \mathrm{mg} \mathrm{g}^{-1}$, respectively) were achieved. Although the water quality in the treated river does not fully meet the standards, dramatically improved esthetic qualities have also been provided to the surrounding area, and the water is suitable for fishing and irrigation. The local government continues to use the drainage system for wastewater, rainwater and sewage discharge. Untreated effluents are discharged directly to the Dihe River during the rainy season, increasing pollution load and degrading the water quality. Therefore, additional techniques such as separation of rainwater and sewage using different drainage systems should be adopted to bring the water quality to the acceptable levels. Furthermore, strengthening the environmental management of wastewater drainage will help water quality to reach the Standards. In contrast to other common methods, combined application is the preferred method for its lower cost, convenience, feasibility and sustainability, the cost was only about $\$ 25,000$ per kilometer in Dihe River. Due to their low maintenance and operational cost requirements together with high removal capacity for different pollutants, this combined application is feasible.

\section{Conclusions}

The comprehensive remediation of a heavily polluted river using a combined application of aeration, microorganisms, biological aerated filters, biofilms and ecological floating beds has been shown to be feasible and effective. After remediation, the average removal rates of $\mathrm{COD}_{\mathrm{Cr}}$, TSS, $\mathrm{NH}_{4}{ }^{+}-\mathrm{N}, \mathrm{TP}$ and $\mathrm{S}^{2-}$ were all above $70 \%$. DO increased from 0.01 to $3.26 \mathrm{mg} \mathrm{L}^{-1}$. Furthermore, the unpleasant odor of $\mathrm{H}_{2} \mathrm{~S}$ emanating from the polluted river has gone. Fish have been reintroduced and are surviving, and many farms began to use the river water for irrigation. The field-scale experiment indicated the feasibility and validity of the method applied to remediate this heavily polluted river. This method could be applied to remediate other similarly polluted rivers.

\section{Acknowledgements}

This work was financially supported by the National Natural Science Foundation of China (Grant No.: 40906045). We acknowledge the contribution of Mr. Tielou Wang and Mr. Peng Chen from the
Changyi Municipal Environmental Protection Bureau for their kind help in the engineering construction and management.

\section{References}

Albuquerque, A., Makinia, J., Pagilla, K., 2012. Impact of aeration conditions on the removal of low concentrations of nitrogen in a tertiary partially aerated biological filter. Ecol. Eng. 44, 44-52.

Alvarez-Vázquez, L.J., Martínez, A., Vázquez-Méndez, M.E., Vilar, M.A., 2009. An application of optimal control theory to river pollution remediation. Appl. Numer. Math. 59, 845-858.

APHA, 1998. Standard Methods for the Examination of Water and Wastewater, 20th ed. American Public Health Association-American Water Works Association, Baltimore, MD.

Arini, A., Feurtet-Mazel, A., Morin, S., Maury-Brachet, R., Coste, M., Delmas, F., 2012 Remediation of a watershed contaminated by heavy metals: a 2-year field biomonitoring of periphytic biofilms. Sci. Total Environ. 425, 242-253.

Beyene, A., Legesse, W., Triest, L., Kloos, H., 2009. Urban impact on ecological integrity of nearby rivers in developing countries: the Borkena River in highland Ethiopia. Environ. Monit. Assess. 153, 461-476.

Brisson, J., Chazarenc, F., 2009. Maximizing pollutant removal in constructed wetlands: should we pay more attention to macrophyte species selection? Sci. Total Environ. 407, 3923-3930.

Cao, W., Zhang, H., Wang, Y., Pan, J., 2012. Bioremediation of polluted surface water by using biofilms on filamentous bamboo. Ecol. Eng. 42, 146-149.

Caraballo, M.A., Macías, F., Rötting, T.S., Nieto, J.M., Ayora, C., 2011. Long term remediation of highly polluted acid mine drainage: a sustainable approach to restore the environmental quality of the Odiel river basin. Environ. Pollut. 159, 3613-3619.

Chen, F., Ding, A., Fu, J., Sheng, G., 2000. Factors influencing the purification efficiency of photosynthetic bacteria. Chin. Sci. Bull. 45, 105-109.

El-Sheikh, M.A., Saleh, H.I., El-Quosy, D.E., Mahmoud, A.A., 2010. Improving water quality in polluted drains with free water surface constructed wetlands. Ecol. Eng. 36, 1478-1484.

Everard, M., Moggridge, H.L., 2012. Rediscovering the value of urban rivers. Urban Ecosyst. 15, 293-314.

Fechner, L.C., Versace, F., Gourlay-Francé, C., Vuillemin, M.T., 2012. Adaptation of copper community tolerance levels after biofilm transplantation in an urban river. Aquat. Toxicol. 106/107, 32-41.

Hadad, H.R., Maine, M.A., 2007. Phosphorous amount in floating and rooted macrophytes growing in wetlands from the Middle Paraná River floodplain (Argentina). Ecol. Eng. 31, 251-258.

Jia, W., Zhang, J., Li, P., Xie, H., Wu, J., Wang, J., 2011. Nitrous oxide emissions from surface flow and subsurface flow constructed wetland microcosms: effect of feeding strategies. Ecol. Eng. 37, 1815-1821.

Khan, S., Afzal, M., Iqbal, S., Khan, Q.M., 2012. Plant-bacteria partnerships for the remediation of hydrocarbon contaminated soils. Chemosphere, http://dx.doi.org/10.1016/j.chemosphere.2012.09.045.

Kido, M., Yustiawati Syawal, M.S., Sulastri Hosokawa, T., Tanaka, S., Saito, T., Iwakuma, T., Kurasaki, M., 2009. Comparison of general water quality of rivers in Indonesia and Japan. Environ. Monit. Assess. 156, 317-329.

Li, M., Wu, Y.J., Yu, Z.L., Sheng, G.P., Yu, H.Q., 2007. Nitrogen removal from eutrophic water by floating-bed-grown water spinach (Ipomoea aquatica Forsk.) with ion implantation. Water Res. 41, 3152-3158.

Li, X.N., Song, H.L., Li, W., Xi, W., Nishimura, O., 2010. An integrated ecological floating-bed employing plant freshwater clam and biofilm carrier for purification of eutrophic water. Ecol. Eng. 36, 382-390.

Longe, E.O., Omole, D.O., 2008. Analysis of pollution status of River Illo, Ota, Nigeria. Environmentalist 28, 451-457.

Lu, L., Tan, H., Luo, G., Liang, W., 2012. The effects of Bacillus subtilis on nitrogen recycling from aquaculture solid waste using heterotrophic nitrogen assimilation in sequencing batch reactors. Bioresour. Technol. 124, 180-185.

Meyer, A., 2012. Intertemporal valuation of river restoration. Environ. Resour. Econ. http://dx.doi.org/10.1007/s10640-012-9580-4. 
Nahlik, A.M., Mitsch, W.J., 2006. Tropical treatment wetlands dominated by freefloating macrophytes for water quality improvement in Costa Rica. Ecol. Eng. 28, 246-257.

Nimrat, S., Suksawat, S., Boonthai, T., Vuthiphandchai, V., 2012. Potential Bacillus probiotics enhance bacterial numbers, water quality and growth during early development of white shrimp (Litopenaeus vannamei). Vet. Microbiol. 159 443-450.

Palmer, M.A., 2009. Reforming watershed restoration: science in need of application and applications in need of science. Estuar. Coasts 32, 1-17.

Perera, E.D.P., Jinno, K., Hiroshiro, Y., 2010. Bacteria-mediated reduction and precipitation of $\mathrm{Fe}(\mathrm{OH})_{3}$ and $\mathrm{FeS}$ in the subsurface of a coastal aquifer: a numerical investigation. Water Qual. Expo. Health 2, 15-30.

Saeed, T., Sun, G., 2012. A review on nitrogen and organics removal mechanisms in subsurface flow constructed wetlands: dependency on environmental parameters, operating conditions and supporting media. J. Environ. Manage. 112, 429-448.

Scholes, L., Faulkner, H., Tapsell, S., Downward, S., 2008. Urban rivers as pollutant sinks and sources: a public health concern for recreational river users? Water Air Soil Pollut:: Focus 8, 543-553.

Shan, B., Ao, L., Hu, C., Song, J., 2011. Effectiveness of vegetation on phosphorus removal from reclaimed water by a subsurface flow wetland in a coastal area. J. Environ. Sci. 23, 1594-1599.

Sheng, Y., Chen, F., Yu, Y., Wang, X., Sheng, G., Fu, J., Zeng, E.Y., 2008. Emission of volatile organic sulfur compounds from a heavily polluted river in Guangzhou, South China. Environ. Monit. Assess. 143, 121-130.

Sheng, Y., Fu, G., Chen, F., Chen, J., 2011. Geochemical characteristics of inorganic sulfur in Shijing River, South China. J. Environ. Monit. 13, 807-812.

Sheng, Y., Chen, F., Sheng, G., Fu, J., 2012. Comprehensive remediation of a heavily polluted river in Guangzhou, South China. Aquat. Ecosyst. Health Manage. 15 219-226.

Slomp, C.P., VanderGaast, S.J., VanRaaphorst, W., 1996. Phosphorous binding by poorly crystalline iron oxides in North Sea sediments. Mar. Chem. 52, 55-73.
Song, H., Li, X., Lu, X., Inamori, Y., 2009. Investigation of microcystin removal from eutrophic surface water by aquatic vegetable bed. Ecol. Eng. 35, 1589-1598.

Sun, L., Liu, Y., Jin, H., 2009. Nitrogen removal from polluted river by enhanced floating bed grown canna. Ecol. Eng. 35, 135-140.

Thiébaut, G., Tixier, G., Guérold, F., Muller, S., 2006. Comparison of different biological indices for the assessment of river quality: application to the upper river Moselle (France). Hydrobiologia 570, 159-164.

Vymazal, J., 2009. The use constructed wetlands with horizontal sub-surface flow for various types of wastewater. Ecol. Eng. 35, 1-17.

Wu, H., Zhang, J., Li, P., Zhang, J., Xie, H., Zhang, B., 2011. Nutrient removal in constructed microcosm wetlands for treating polluted river water in northern China. Ecol. Eng. 37, 560-568.

Wu, S., Kuschk, P., Wiessner, A., Müller, J., Saad, R.A.B., Dong, R., 2012. Sulphur transformations in constructed wetlands for wastewater treatment: a review. Ecol. Eng., http://dx.doi.org/10.1016/j.ecoleng.2012.11.003.

Yang, J., Wang, S., Lu, Z., Yang, J., Lou, S., 2009. Converter slag-coal cinder columns for the removal of phosphorous and other pollutants. J. Hazard. Mater. 168, 331-337.

Zhang, Y.L., Dai, J.L., Wang, R.Q., Zhang, J., 2008. Effects of long-term sewage irrigation on agricultural soil microbial structural and functional characterizations in Shandong, China. Eur. J. Soil Biol. 44, 84-91.

Zhao, Z., Zhong, G., Möller, A., Xie, Z., Sturm, R., Ebinghaus, R., Tang, J., Zhang, G. 2011. Levels and distribution of Dechlorane Plus in coastal sediments of the Yellow Sea, North China. Chemosphere 83, 984-990.

Zhao, F., Xi, S., Yang, X., Yang, W., Li, J., Gu, B., He, Z., 2012. Purifying eutrophic river waters with integrated floating island systems. Ecol. Eng. 40, 53-60.

Zhong, G., Tang, J., Zhao, Z., Pan, X., Chen, Y., Li, J., Zhang, G., 2011. Organochlorine pesticides in sediments of Laizhou Bay and its adjacent rivers, North China. Mar. Pollut. Bull. 62, 2543-2547.

Zhu, L.D., Li, Z.H., Ketola, T., 2011. Biomass accumulations and nutrient uptake of plants cultivated on artificial floating beds in China's rural area. Ecol. Eng. 37, $1460-1466$ 